\title{
Relation among blood plasma total lipids, cholesterol, glucose and urea concentrations, and reproductive performance in Bohemian Spotted cows*
}

\author{
L. Máchal, G. Chládek and J. Žižlavský \\ Mendel University of Agriculture and Forestry \\ Zemédélská 1, 61300 Brno, Czech Republic
}

(Received 16 June 1998; accepted 19 March 1999)

\begin{abstract}
Blood samples were taken, in monthly intervals, for 12 months from Bohemian Spotted cows between 20 and 100 days post partum for total lipids, cholesterol, glucose and urea determination. In all, 208 cows were sampled to define the relation between reproductive performance and concentration of biochemical plasma indicators. Reproductive performance was characterized by the length of the interval (average 79.67 days), service period (average 113.64 days) and insemination index (average 1.67). Average values for the entire studied period were $5.33 \mathrm{mmol} \cdot \mathrm{l}^{-1}$ for plasma urea, $3.16 \mathrm{~g} \cdot \mathrm{l}^{-1}$ for total lipids, $3.93 \mathrm{mmol} \cdot \mathrm{l}^{-1}$ for cholesterol and $3.93 \mathrm{mmol} \cdot \mathrm{l}^{-1}$ for glucose. During the investigations the length of the interval decreased from 111.39 days to 73.57 days and service period from 137.06 days to 84.61 days. The average concentrations of urea and total lipids changed in the individual months depending on changes in feed rations. Calculated correlations between the respective biochemical blood indicators and studied reproductive indicators changed in the same way. Indicators of reproductive performance were affected by the internal environment, particularly in the case of low lipaemia, and, in contrast, in the case of high blood plasma uremia.
\end{abstract}

KEY WORDS: Bohemian Spotted cows, reproductive performance, urea, total lipid, cholesterol, glucose

\section{INTRODUCTION}

The first 100 days of lactation is the period of the most intensive metabolism when the cow produces nearly $50 \%$ of milk for lactation and after successful puer-

\footnotetext{
* Supported by EP 7159 NAZV CR and CEZ J08/98:432100001
} 
perium is expected to conceive. This is a period of increased energy requirements, frequently reflected in energy imbalance and reproductive disorders. Indicators providing information about energy insufficiency include both blood plasma lipaemia and glycaemia. Ruegg et al. (1992) concluded that conception by cows with higher concentrations of serum cholesterol was higher. Also Hang-Poung (1989) found that conception of Holstein cows was positively related with serum cholesterol concentration. Vhora et al. (1995) reported a higher level of serum cholesterol in cycling cows than in anoestrous ones. However, the difference was not highly significant. Haraszti et al. (1985) consider the concentration of serum cholesterol to be an indicator suitable for prediction of reproductive performance. Similarly, Máchal et al. (1996) found that conception was more successful in cows with higher concentration of serum cholesterol and total lipids. Based on studies of changes in concentration of total lipids during gravidity and the first two months of lactation, Kampl et al. (1990) observed its increase in the post partum period, with the highest value around the 30th day. Mansfeld et al. (1996) drew attention to the relation between glucose level and fertility of cows. They found that plasma glucose levels were significantly higher in cows with fertility disorders than in cows with no disorders. Kolver and MacMillan (1994) observed marked changes in the concentrations of plasma glucose and urea in the post partum period of 40 Jersey or Holstein-Friesian cows, and a significantly important interaction between urea concentration and changes in the feed ration. Kreuzer et al. (1991) found changes in plasma urea of cows based on $11.6,14.5$ or $17.1 \%$ crude protein in diets. Ferguson et al. (1993) evaluated $627 \mathrm{AI}$ in 332 Holstein cows in nine herds and found that the conception rate decreased with serum urea $\mathrm{N}>14.9 \mathrm{mg} / \mathrm{dl}$. Dirksen et al. (1997) found that high concentrations of plasma urea may have a negative effect on fertility. Miettinen (1991) reported shorter intervals from calving to first insemination in the group with high glucose and high urea levels than in the group with low values.

\section{MATERIAL AND METHODS}

The 12 months of investigations, from November 1996 till October 1997, encompassed 208 Bohemian Spotted cows. Studied was the relation among blood plasma urea, cholesterol, glucose and total lipid concentrations, and reproductive performance. Blood samples for total lipids, cholesterol, glucose and urea were taken from cows from 20 to 100 days post partum. Blood samples, analyzed for concentrations of biochemical blood indicators, were taken once a month from cows at least 20 but not more than 100 days after calving. The observation was conducted on only clinically healthy cows, without apparent reproductive pathologies after successful puerperium. These cows were in their 1 st to 8 th lactations, on average 3.34 lactations. The numbers of cows in the groups ranged between 19 
and 29. During the whole calendar year, 262 blood samples were taken from cows of the herd to determine the concentrations of selected blood indicators. Blood was taken either from the vena coccygea mediana or from the vena subcutanea abdominis. Blood samples were always taken between 8 and 11 a.m.

Concentrations of selected blood indicators (total lipids, cholesterol, glucose and urea) were determined from blood plasma within $24 \mathrm{~h}$ (colorimetric method using Bio-La assays).

In the first sampling month (November 1996) the feed ration was optimized and fed the whole period of investigations. The ration was based on maize, barley and clover-grass silage with about $35 \%$ of concentrates. From May 1997 the clovergrass silage was eliminated and substituted with unpreserved green forage.

The average annual performance for one cow was $6,850 \mathrm{~kg}$ of milk, $278 \mathrm{~kg}$ of fat and $231 \mathrm{~kg}$ of protein. The detection of cows in heat was conducted twice a day; the staff of the breeding organization inseminated the cows regularly with semen from twenty-three different Bohemian Spotted bulls. The reproduction performance of each cow was based on the interval (I), i.e. period from calving to first insemination, service period (SP), i.e. period from calving to conception, and insemination index (II), i.e. number of inseminations required for the cows to conceive.

The selected reproduction traits (I, SP and II) and determined values of total lipids (TL), cholesterol (Chol), glucose (Gluc) and urea (U) were evaluated statistically. The correlations were defined using the calculated phenotypic correlations for every month and together for the whole year.

\section{RESULTS}

The average values of reproductive indicators and selected biochemical blood parameters in the individual months, as well as the dynamics of the values for the entire 12 months of investigations, are given in Table 1. Blood was sampled on average 54.52 days after calving; in the individual months this interval ranged between 46.33 and 64.80 days. The average length of the interval for the whole 12-month period was 79.67 days, with the highest values at the beginning of this period (November 1996), i.e. 111.39 days, and the lowest at the end (September 1997), i.e. 64.89 days; the values dropped rapidly as early as January 1997 to 77.67 days. The dynamics of the length of the service period were similar, with maximal values in November 1996 (137.06 days) and the lowest again at the end of the studied period (84.61 days). The average length of the service period for the whole studied period was 113.64 days. The average value of the insemination index was 1.67 ; values were the highest in March and April 1997 (1.94 and 1.95, respectively), the lowest in November 1996 and October 1997 (1.35 and 1.39, respectively). Figure 1 shows the dynamics of reproduction parameters. Like the reproductive parameters, the 
TABLE 1

The average values of the reproduction efficiency and blood plasma values in the Bohemian Spotted cows in the first 100 days after calving (November 1996 till October 1997)

\begin{tabular}{|c|c|c|c|c|c|c|c|c|c|c|}
\hline $\begin{array}{l}\text { Month } \\
\text { and year }\end{array}$ & $\mathrm{n}$ & $\begin{array}{l}\text { Days after } \\
\text { calving }\end{array}$ & $\begin{array}{l}\text { Order of the } \\
\text { lactation }\end{array}$ & $\begin{array}{l}\text { Total } \\
\text { lipids }\end{array}$ & Cholesterol & Glucose & Urea & Interval & $\begin{array}{l}\text { Service } \\
\text { periode }\end{array}$ & $\begin{array}{c}\text { Insemination } \\
\text { index }\end{array}$ \\
\hline XI.96 & 21 & $46.33 \pm 17.10$ & $3.28 \pm 1.49$ & $2.41 \pm 0.82$ & $2.71 \pm 0.51$ & $4.57 \pm 0.85$ & $8.66 \pm 2.19$ & $111.39 \pm 50.86$ & $137.06 \pm 62.47$ & $1.35 \pm 0.70$ \\
\hline XII.96 & 29 & $55.97 \pm 21.49$ & $3.86 \pm 1.63$ & $2.66 \pm 0.39$ & $4.34 \pm 1.02$ & $3.62 \pm 0.58$ & $6.06 \pm 1.63$ & $102.85 \pm 45.38$ & $128.15 \pm 60.27$ & $1.42 \pm 0.76$ \\
\hline 1.97 & 23 & $49.48 \pm 18.21$ & $3.59 \pm 1.68$ & $2.78 \pm 0.55$ & $3.25 \pm 0.67$ & $3.38 \pm 0.65$ & $8.20 \pm 1.36$ & $77.67 \pm 36.68$ & $129.47 \pm 71.41$ & $1.79 \pm 1.18$ \\
\hline II.97 & 24 & $48.67 \pm 19.18$ & $3.73 \pm 1.55$ & $3.42 \pm 1.02$ & $4.60 \pm 0.88$ & $3.90 \pm 0.58$ & $4.77 \pm 1.52$ & $66.09 \pm 16.55$ & $114.60 \pm 51.22$ & $1.90 \pm 1.12$ \\
\hline III.97 & 21 & $48.86 \pm 20.99$ & $3.90 \pm 1.29$ & $3.44 \pm 0.98$ & $3.94 \pm 1.17$ & $3.40 \pm 0.66$ & $4.84 \pm 0.73$ & $74.26 \pm 21.56$ & $118.18 \pm 42.72$ & $1.94 \pm 1.14$ \\
\hline IV.97 & 24 & $61.63 \pm 16.24$ & $3.63 \pm 1.58$ & $3.17 \pm 0.83$ & $3.07 \pm 0.83$ & $3.99 \pm 0.51$ & $4.41 \pm 1.16$ & $70.48 \pm 25.68$ & $117.79 \pm 52.70$ & $1.95 \pm 1.13$ \\
\hline V.97 & 19 & $50.53 \pm 18.27$ & $3.58 \pm 2.01$ & $3.47 \pm 1.15$ & $4.46 \pm 0.93$ & $3.86 \pm 1.00$ & $4.34 \pm 1.07$ & $66.68 \pm 26.00$ & $106.24 \pm 53.48$ & $1.82 \pm 1.13$ \\
\hline VI.97 & 20 & $54.75 \pm 18.21$ & $3.00 \pm 2.34$ & $3.19 \pm 0.84$ & $4.45 \pm 1.19$ & $4.17 \pm 0.87$ & $3.42 \pm 1.02$ & $68.16 \pm 24.57$ & $117.79 \pm 59.32$ & $1.78 \pm 0.88$ \\
\hline VII.97 & 21 & $53.95 \pm 17.68$ & $2.52 \pm 1.86$ & $2.92 \pm 0.65$ & $4.16 \pm 1.32$ & $4.71 \pm 1.09$ & $4.92 \pm 1.25$ & $79.95 \pm 30.68$ & $101.39 \pm 49.60$ & $1.56 \pm 0.86$ \\
\hline VIII.97 & 25 & $64.80 \pm 20.22$ & $2.83 \pm 1.72$ & $3.49 \pm 0.86$ & $4.12 \pm 0.95$ & $3.56 \pm 1.08$ & $4.03 \pm 0.88$ & $93.04 \pm 50.80$ & $105.00 \pm 35.69$ & $1.59 \pm 0.80$ \\
\hline IX.97 & 19 & $56.47 \pm 19.83$ & $2.89 \pm 1.49$ & $3.43 \pm 1.20$ & $4.20 \pm 0.76$ & $4.53 \pm 0.89$ & $5.11 \pm 0.90$ & $64.89 \pm 17.77$ & $92.60 \pm 45.05$ & $1.60 \pm 0.91$ \\
\hline X.97 & 23 & $59.91 \pm 24.22$ & $3.04 \pm 1.58$ & $3.70 \pm 1.13$ & $3.68 \pm 0.97$ & $3.58 \pm 0.80$ & $5.51 \pm 1.16$ & $73.57 \pm 19.21$ & $84.61 \pm 39.53$ & $1.39 \pm 0.78$ \\
\hline Total & 281 & $54.52 \pm 19.91$ & $3.34 \pm 1.72$ & $3.16 \pm 0.95$ & $3.93 \pm 1.12$ & $3.93 \pm 0.91$ & $5.33 \pm 1.95$ & $79.67 \pm 35.69$ & $113.64 \pm 54.14$ & $1.67 \pm 0.96$ \\
\hline
\end{tabular}




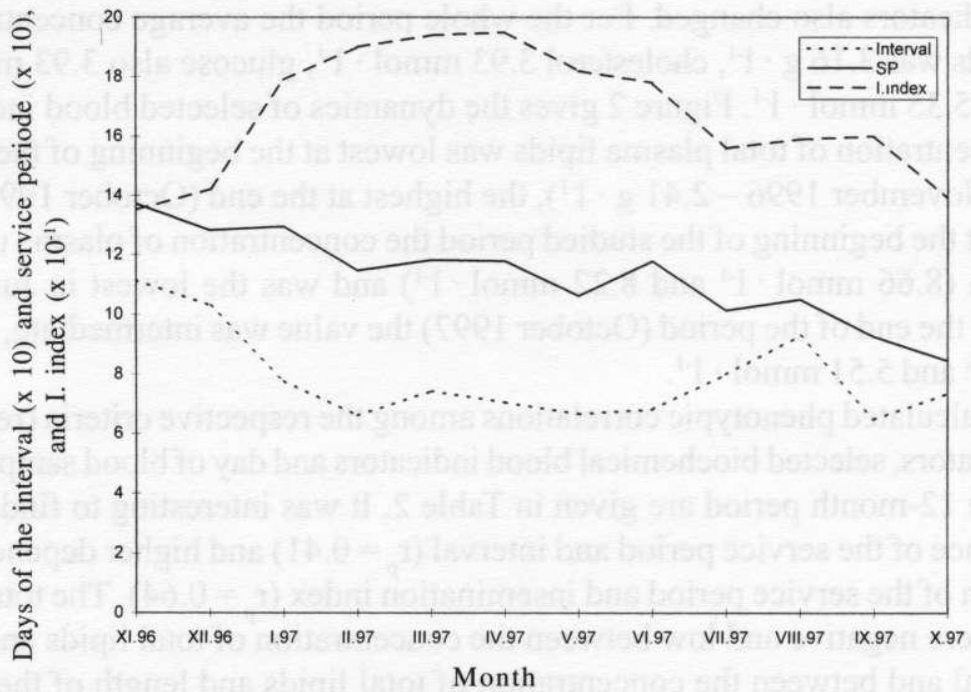

Figure 1. The dynamics of the reproductive parameters in the Bohemian Spotted cows - from 20 to 100 days post partum (XI. $96-$ X. 97)

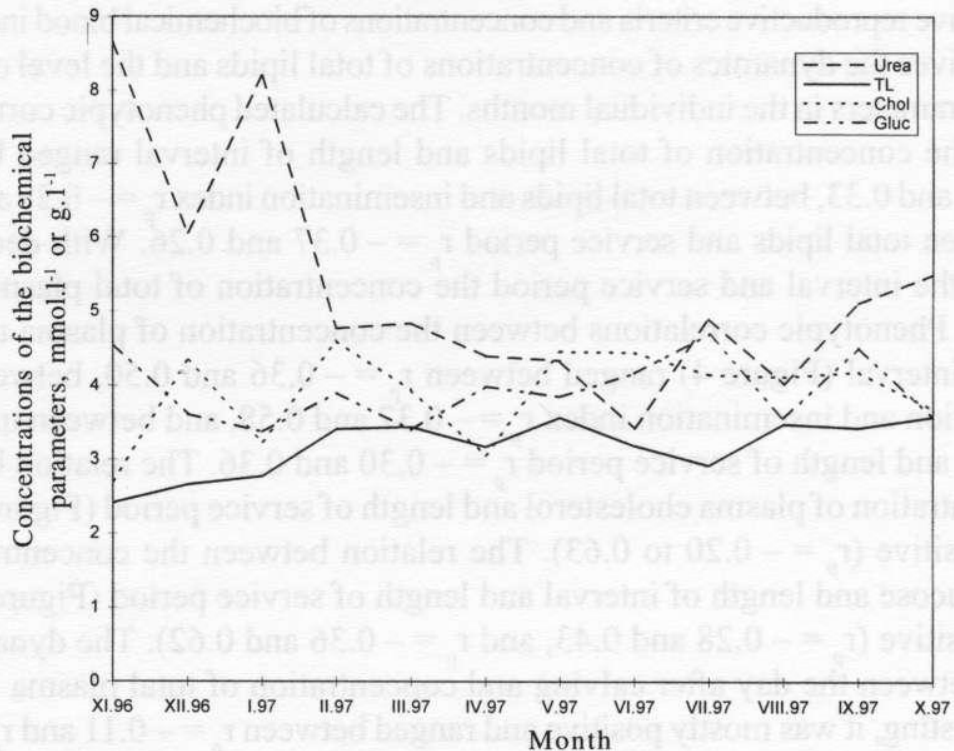

Figure 2. The dynamics of the biochemical parameters in the Bohemian Spotted cows - from 20 to 100 days post partum (XI. $96-$ X. 97) 
blood indicators also changed. For the whole period the average concentration of total lipids was $3.16 \mathrm{~g} \cdot \mathrm{l}^{-1}$, cholesterol $3.93 \mathrm{mmol} \cdot \mathrm{l}^{-1}$, glucose also $3.93 \mathrm{mmol} \cdot \mathrm{l}^{-1}$ and urea $5.35 \mathrm{mmol} \cdot 1^{-1}$. Figure 2 gives the dynamics of selected blood indicators. The concentration of total plasma lipids was lowest at the beginning of the studied period (November $1996-2.41 \mathrm{~g} \cdot 1^{-1}$ ), the highest at the end (October $1997-3.70$ $\left.\mathrm{g} \cdot \mathrm{l}^{-1}\right)$. At the beginning of the studied period the concentration of plasma urea was also high $\left(8.66 \mathrm{mmol} \cdot 1^{-1}\right.$ and $\left.8.22 \mathrm{mmol}^{-1^{-1}}\right)$ and was the lowest in June 1997 (3.42); at the end of the period (October 1997) the value was intermediate, i.e. 5.11 $\mathrm{mmol} \cdot \mathrm{l}^{-1}$ and $5.51 \mathrm{mmol} \cdot \mathrm{l}^{-1}$.

The calculated phenotypic correlations among the respective criteria (reproductive indicators, selected biochemical blood indicators and day of blood sampling) for the entire 12-month period are given in Table 2. It was interesting to find a lower dependence of the service period and interval $\left(r_{p}=0.41\right)$ and higher dependence of the length of the service period and insemination index $\left(r_{p}=0.64\right)$. The total correlations were negative and low between the concentration of total lipids and length of interval and between the concentration of total lipids and length of the service period $\left(r_{p}=-0.13\right.$ and $r_{p}=-0.10$, respectively). The relation between glucose concentration and length of interval was low and positive $\left(r_{p}=0.11\right)$, as was the relation between cholesterol and urea concentrations and length of the service period $\left(r_{p}=0.10\right.$ and $r_{p}=0.15$, respectively). The relation between the day after calving and concentration of total lipids, and/or cholesterol, was positive $\left(r_{p}=0.20\right.$ and $r_{p}=0.26$, respectively). Table 3 shows the dynamics of the relation between the respective reproductive criteria and concentrations of biochemical blood indicators. Figure 3 gives the dynamics of concentrations of total lipids and the level of reproductive parameters in the individual months. The calculated phenotypic correlations between the concentration of total lipids and length of interval ranged between $r_{p}=-0.40$ and 0.33 , between total lipids and insemination index $r_{p}=-0.28$ and 0.43 , and between total lipids and service period $r_{p}=-0.37$ and 0.26 . With decreasing values of the interval and service period the concentration of total plasma lipids increased. Phenotypic correlations between the concentration of plasma urea and length of interval (Figure 4) ranged between $r_{p}=-0.36$ and 0.50 , between urea concentration and insemination index $r_{p}=-0.32$ and 0.58 , and between urea concentration and length of service period $r_{p}=-0.30$ and 0.36 . The relation between the concentration of plasma cholesterol and length of service period (Figure 5) was mostly positive $\left(r_{p}=-0.20\right.$ to 0.63$)$. The relation between the concentration of plasma glucose and length of interval and length of service period (Figure 6) was mostly positive $\left(r_{p}=-0.28\right.$ and 0.43 , and $r_{p}=-0.36$ and 0.62$)$. The dynamics of relation between the day after calving and concentration of total plasma lipids is very interesting, it was mostly positive and ranged between $r_{p}=-0.11$ and $r_{p}=0.45$. 
Estimation of correlation coefficient (total 12 month's average)

TABLE 2

\begin{tabular}{|c|c|c|c|c|c|c|c|c|c|c|}
\hline Indices & & $\begin{array}{c}\text { Day post } \\
\text { partum }\end{array}$ & Interval & $\begin{array}{l}\text { Service } \\
\text { period }\end{array}$ & $\begin{array}{l}\text { Insemination } \\
\text { index }\end{array}$ & $\begin{array}{l}\text { Order of the } \\
\text { lactation }\end{array}$ & $\begin{array}{l}\text { Total } \\
\text { lipids }\end{array}$ & Cholesterol & Glucose & Urea \\
\hline Day post partum & & 1 & & & & & & & & \\
\hline Interval & & 0.17 & 1 & & & & & & & \\
\hline Service periode & & 0.10 & 0.41 & 1 & & & & & & \\
\hline dex & & & & 0.64 & 1 & & & & & \\
\hline Order of the lactation & & -0 & & & & 1 & & & & \\
\hline Total lipids & & & -0.1 & -0.10 & 0.05 & -0.03 & 1 & & & \\
\hline Cholesterol & & 0.26 & -0.08 & 0.10 & 0.09 & -0.02 & 0.26 & 1 & & \\
\hline Glucose & & & & & 0.03 & & -0.04 & 0.06 & 1 & \\
\hline Urea & & -0.07 & 0.09 & 0.15 & -0.02 & -0.09 & -0.20 & -0.24 & -0.02 & 1 \\
\hline
\end{tabular}




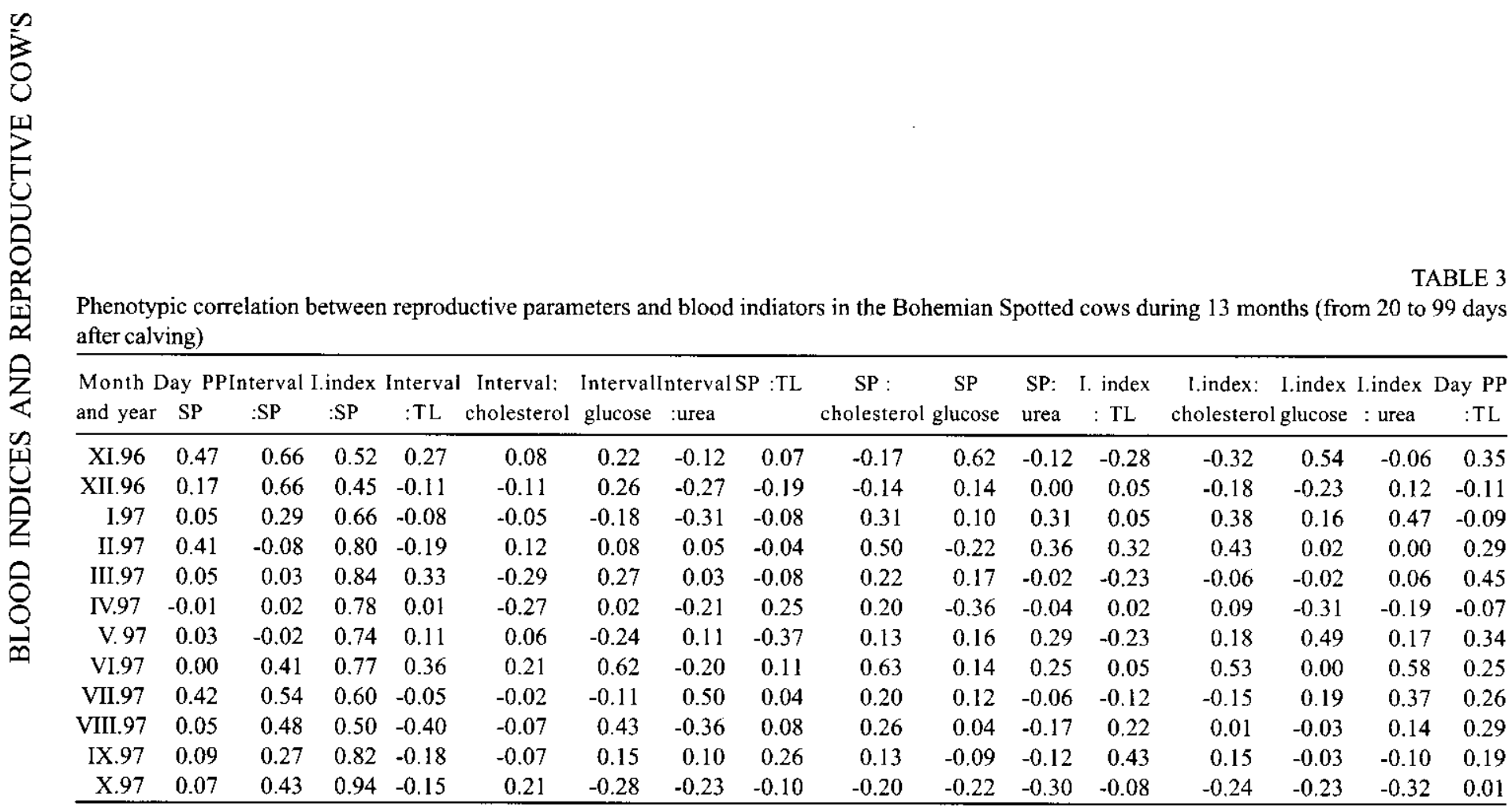




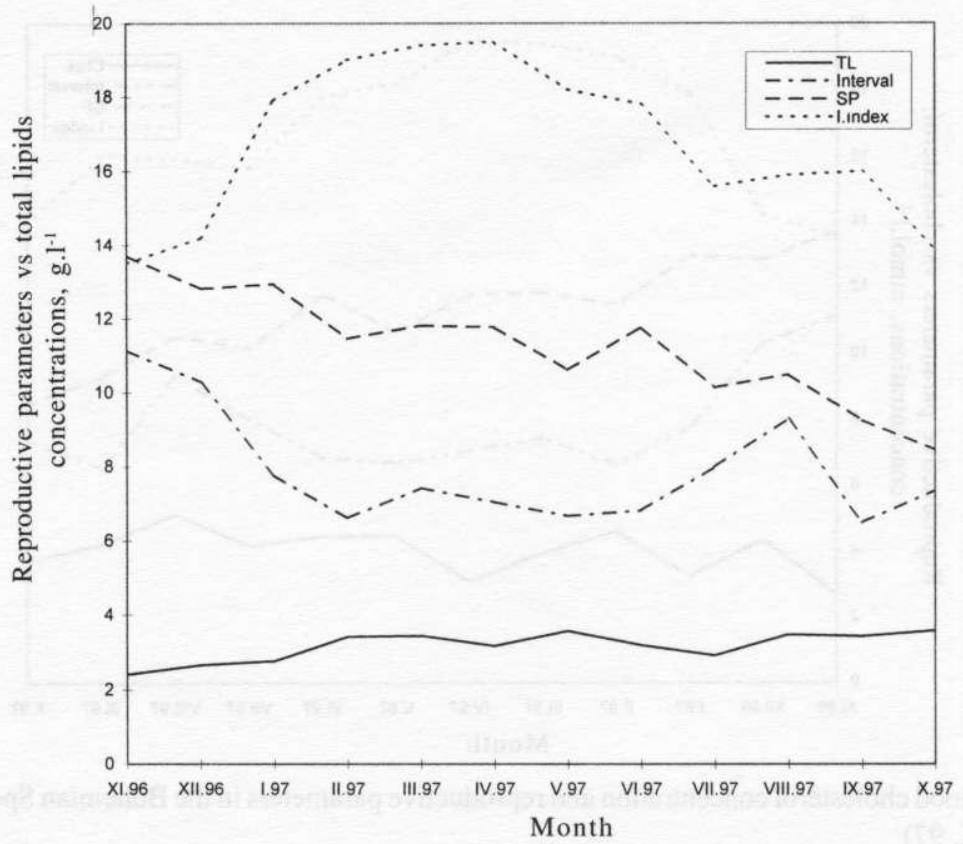

Figure 3. Blood total lipids concentration and reproductive parameters in the Bohemian Spotted cows (XI. $96-$ X. 97)

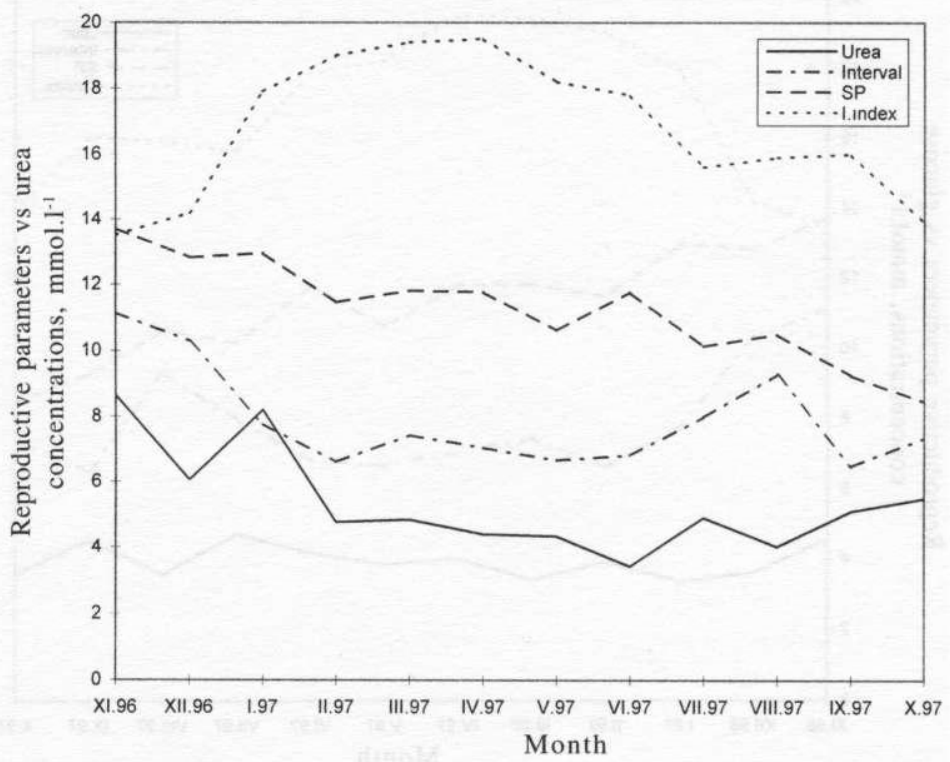

Figure 4. Blood urea concentration and reproductive parameters in the Bohemian spotted cows (XI. $96-$ X. 97) 


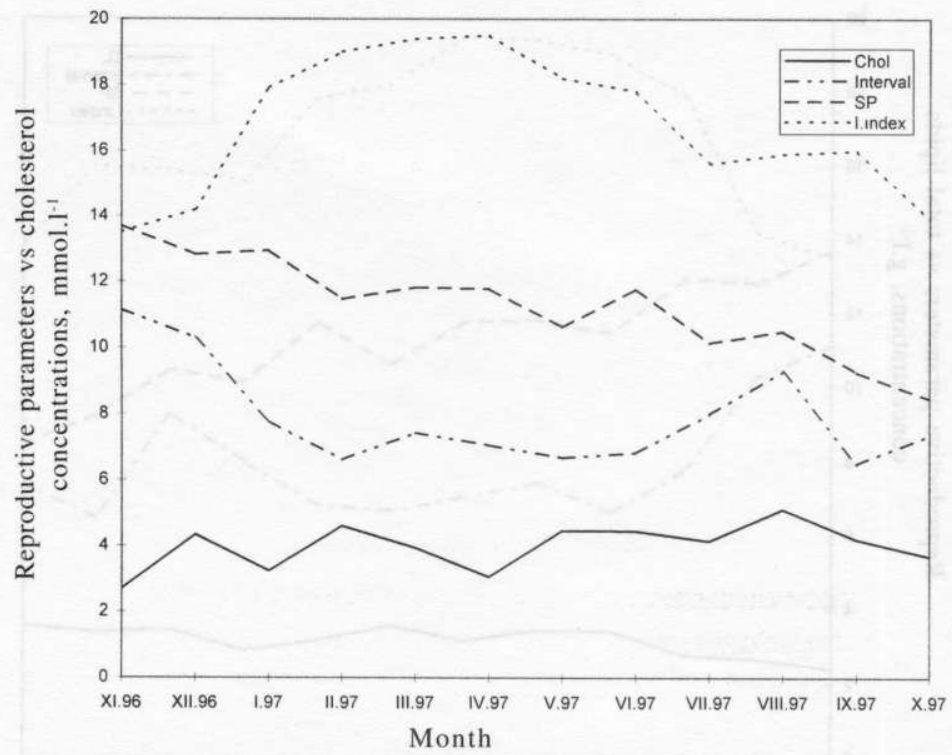

Figure 5. Blood cholesterol concentration and reproductive parameters in the Bohemian Spotted cows (XI. $96-$ X. 97)

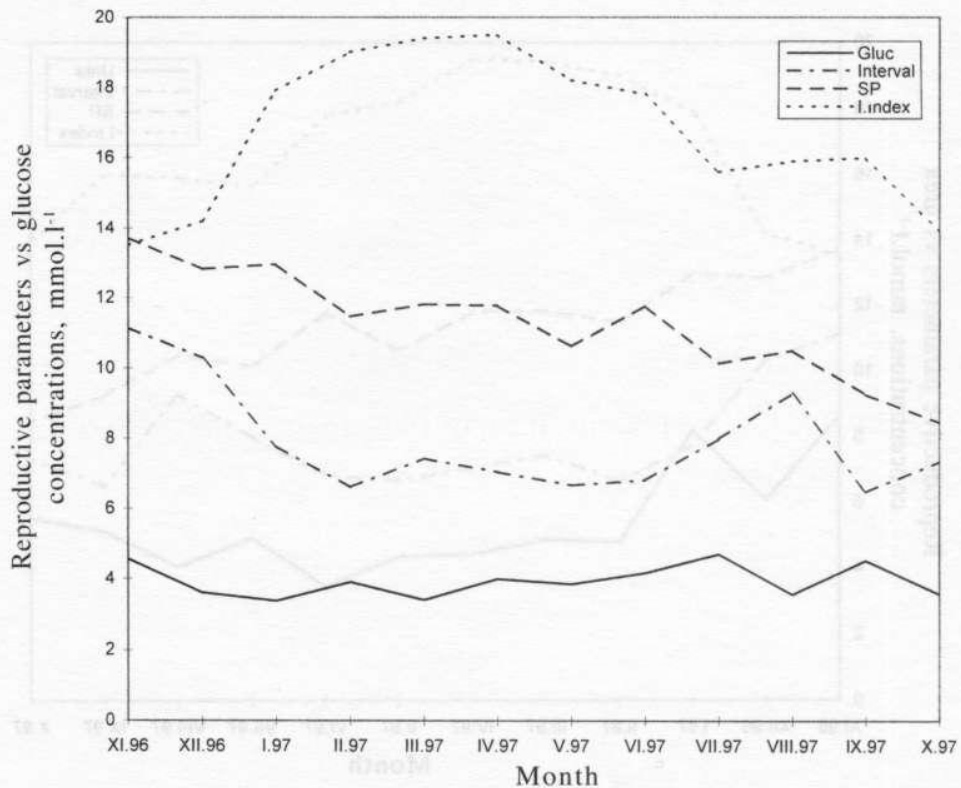

Figure 6. Blood glucose concentration and reproductive parameters in the Bohemian Spotted cows (XI. 96 - X. 97) 


\section{DISCUSSION}

The first indicator of energetic imbalance at high lactation when the feed ration is unbalanced is lower reproduction performance. In the present paper we found relatively high average values of the interval ( 76.67 days) and service period (113.64 days). The value of the average insemination index was relatively good (1.67). The gradual decrease in average monthly values of interval length (period from calving to first insemination) from 111.39 days (November 1996) to 64.89 and 79.67 days (September and October, 1997, respectively) squared with the slow increase in average monthly concentrations of total plasma lipids from $2.41 \mathrm{~g} \cdot \mathrm{I}^{-1}$ in November 1996 to $3.70 \mathrm{~g} \cdot \mathrm{I}^{-1}$ in October 1997 . The reduction of the average interval length by 37.82 days was accompanied by a radical reduction in the service period from 137.06 days to 84.61 days, i.e. by 52.45 days, and at the end of the studied period this value approached the average value of the interval, being only 11.04 days higher. During investigations the average insemination index increased from the initial 1.35 to 1.95 days. After consolidation of the dynamics of blood parameters (urea and total lipid concentrations) from July 1997 to the end of the studied period it decreased to 1.39 and was most likely associated with urea dynamics, or its increase to maximal or, on the other hand, decrease to minimal values. In the studied breed of dual-purpose cattle the shortening of the interval along with the shortening of the SP by ca $38 \%$ and slight increase in the insemination index appears to be desirable even if the insemination costs are higher, resulting in increased average values of the insemination index.

The average values of the concentration of total plasma lipids $\left(3.16 \mathrm{~g} \cdot 1^{-1}\right)$ and cholesterol $\left(3.93 \mathrm{mmol} \cdot 1^{-1}\right)$ for the entire studied year represent an average range of normal values. The average glucose concentration $\left(3.93 \mathrm{mmol} \cdot 1^{-1}\right)$ gives the upper limit value of the normal range. The average concentration of plasma urea for the whole studied period $\left(5.33 \mathrm{mmol} \cdot \mathrm{l}^{-1}\right)$ exceeded the upper limit of normal values. The low values of plasma lipaemia and high values of uremia at the beginning of the studied period showed that the feed ration was unbalanced, with excess protein and lack of energy (Kreuzer et al., 1991; Roseler et al., 1993; Kolver and MacMillan, 1994). Urea concentration considerably decreased in May and June 1997, resulting in a temporary increase in the insemination index. This finding is in consistent with Miettinen (1991). In terms of the interval length, moderately negative correlations $\left(r_{p}=-0.31\right.$ to -0.12$)$ appear when the concentration of plasma urea is high. Towards the end of the studied period, when the average plasma urea concentration increased, intermediate negative correlations between the urea concentration and length of service period were obtained $\left(r_{p}=-0.06\right.$ and -0.30$)$. Miettinen (1991) presented similar results. However, the findings of Ferguson et al. (1993) for this dual-purpose commercial type of cattle were not confirmed. In terms of the relation between plasma lipaemia and reproductive performance, the domi- 
nating relation is between total lipid concentration and interval length, and similarly also between the concentration of cholesterol and interval length. Interesting are also the calculated negative phenotypic correlations between interval length and concentration of total lipids in months when average monthly concentrations increased markedly (from November 1996 to February 1997, and from August 1997 to October 1997). These correlations are negative and in the first period they range between $r_{p}=-0.19$ and -0.08 , in the 2 nd period $r_{p}=-0.40$ and -0.05 . At the beginning of the investigations, when the concentrations of total lipids were low, the correlations between concentrations of total lipids and length of the service period were low and negative $\left(r_{p}=-0.04\right.$ and -0.19$)$, and when the concentrations were higher at the end of investigations they were low and positive $\left(r_{p}=0.04\right.$ and 0.26 ), with the exception of the last month. In months when the concentration of plasma cholesterol decreased, the relations between cholesterol concentration and interval length were negative (November 1996 and January 1997, $r_{p}=-0.11$ and -0.05 , March and April 1997, $\mathrm{r}_{\mathrm{p}}=-0.29$ and -0.27 , from July to September 1997, $r_{p}=-0.02$ and -0.07$)$. The effect of the concentration of plasma glucose is mostly only momentary and does not appear until the energy intake is more balanced. The relations found between plasma lipaemia and level of reproductive indicators of cows are in accordance with the findings of Haraszti et al. (1985), Ruegg et al. (1993), Vhora et al. (1995) and Máchal et al. (1996). The calculated correlation coefficient between the day of blood sampling (20th to 100th day post partum) showed a predominantly positive dependence over the entire studied period $\left(r_{p}=0.01\right.$ and 0.45 ), with the exception of three months when the correlation was low and positive $\left(r_{p}=-0.11\right.$ and 0.07$)$. Therefore, the concentration of total plasma lipids mostly increased over the entire period between the 20th and 100th days post partum. We cannot confirm the finding of Kampl et al. (1990) that the concentration of total plasma lipids is the highest 30 days after calving. Unfortunately, we did not observe cholesterol fraction values and free fatty acids, it would be appropriate to consider them in further work.

Indicators of reproductive performance of cows are, therefore, affected by the internal environment, particularly negatively when there is an abnormal increase or decrease in the concentration of plasma urea, and also of total lipids and cholesterol. Decisive is not the overall relation between the individual averages of biochemical indicators for the entire period and the reproductive indicators, but the momentary condition depending on the immediate concentrations of the respective blood indicators.

\section{REFERENCES}

Dirksen G., Hagertheen C., Alexanderkatz. M., Berger A., 1997. Monitoring of dairy cows for metabolic imbalances during high lactation by means of milk parameters. 1. Daily milk yield, fat and protein concentrations, fat-protein-quotient and urea concentration. Tierarztl. Umsch. 52, 319-324 
Ferguson J.D., Galligan D.T., Blanchard T., Reeves M., 1993. Serum urea nitrogen and conception rate: the usefulness of test information. J. Dairy Sci. 76, 3742-3746

Hang-Poung F., 1989. The relationship between the seasonal serum biochemical profile and reproductive performance in perinatal Holstein cows. Taiwan J. Vet. Med. Anim. Husb. 54, 1-19

Haraszti J., Huszenica G.Y., Molnár L., Csernus V., 1985. Postpartal ovarian activity of healthy cows and those affected by subclinical metabolic disorders. Anim. Reprod. Sci. 37, 125-136

Kampl B., Matinčič T., Catinelli M., Susnjič M., 1990. Profiles of selected biochemical blood parameters in dairy cows during gravidity and lactation and their influence on milk production and reproductive efficiency. I. Total lipids and total cholesterol and its fractions in blood. Vet. Arch. $60,293-305$

Kolver E. S., MacMillan K. L., 1994. Variation in selected blood plasma constituents during the postpartum and breeding periods in dairy cows. NZ Vet. J. 42, 161-166

Kreuzer M., Kirchgessner M., Blum J.W., 1991. Concentrations of hormones and metabolites in blood plasma of cows during and subsequent to different crude protein supply. J Anim. Physiol. Anim. Nutr. 65,11-20

Máchal L., Gerža M., Doležal P., 1996. Blood plasma lipemia in the post partum period in cows in relation to their conception (in Czech). Živoč. Výroba 41, 5-8

Mansfeld R., Gruneberg W., Thiemann E., Grunert E., 1996. Statistical analysis of blood and saliva metabolic profiles as a tool in diagnosis of herd disorders. Züchtungskunde 68, 325-345

Miettinen P.V.A., 1991. Correlation between energy balance and fertility in Finish dairy cows. Acta Vet. Scand. 32, 189-196

Ruegg P.L., Goodger W.J., Holmberg C.A., Weaver L.D., Huffman E M., 1992. Relation among body condition score, serum urea nitrogen and cholesterol concentrations, and reproductive performance in high-producing Holstein dairy cows in early lactation. Amer. J. Vet. Res. 53, 10-14

Vhora S.C., Dindorkar C.V., Kaikini A.S., 1995. Studies on blood serum levels of certain biochemical constituents in normal cycling and anestrous crossbred cows. Indian J. Anim. Reprod. 16, 85-87

\section{STRESZCZENIE}

Zależność pomiędzy zawartością lipidów, cholesterolu, glukozy i mocznika w surowicy krwi a wynikami reprodukcyjnymi u krów rasy czeskiej srokatej

W doświadczeniu na 208 krowach rasy czeskicj srokatcj pobierano co miesiąc przez 12 miesięcy próby krwi, w których średnie stężenie mocznika wynosiło $5,33 \mathrm{mmola}$; lipidów ogólnych $3,16 \mathrm{~g} / \mathrm{l}$; cholesterolu 3,93 mmola i glukozy 3,93 mmola. Średnie stężenie mocznika i lipidów zmieniało się w poszczególnych miesiącach w zależności od zmian w składzie dawki pokarmowej.

Wyniki reprodukcyjne krów określano na podstawie liczby dni między wycieleniami (średnio 79,7 dni), okresu do skutecznego zacielenia (średnio 113,6 dni) oraz indeksu inseminacyjnego (średnio 1,67). W ciągu doświadczenia liczba dni między wycieleniami obniżyła się z 111,4 do 73,6 , a okres do skutecznego zacielenia z 137,1 do 86,6 dni.

Stwierdzono zależność wskaźników reprodukcyjnych od stężenia poszczególnych metabolitów we krwi, szczególnie zaś od stężenia lipidów i mocznika, których nadmierne zwiększenie lub obniżenie ujemnie odbijało się na wynikach reprodukcyjnych. 